\title{
ANALISIS EFEKTIVITAS DAN EFISIENSI PELAPORAN TENAGA KERJA DENGAN MENGGUNAKAN SISTEM MANUAL DAN SISTEM ONLINE (STUDI KASUS BPJS KETENAGAKERJAAN CABANG GRESIK)
}

\author{
Sasongko Budi Laksono \\ Program Studi Manajemen Fakultas Ekonomi dan Bisnis \\ Universitas Muhammadiyah Gresik
}

\begin{abstract}
This study aims to determine the effectiveness and efficiency of employment reporting in the office BPJS Employment Ketenagakerjaan Gresik. Using 6 informants from BPJS Ketenagakerjaan employee and 4 informants from the participant to know comparison of effectiveness and efficiency of reporting in BPJS Ketenagakerjaan of Gresik. The analysis was done by using constant comparative analysis technique. The results show that Online reporting application meets the indicators of effectiveness and efficiency.
\end{abstract}

Keywords: Reporting, Manual System, Online System

\section{PENDAHULUAN}

Seiring dengan perkembangan teknologi di era globalisasi ini, dunia usaha berlomba-lomba untuk meningkatkan mutu dalam rangka mengembangkan perusahaan untuk meningkatkan persaingan. Semakin berkembangnya dunia usaha akan semakin banyak muncul berbagai perusahaan, baik perusahaan dagang maupun perusahaan jasa. Hal ini akan menimbulkan tingkat persaingan yang semakin ketat, sehingga mengharuskan manajemen perusahaan mengambil kebijakan-kebijakan agar perusahaan dapat tetap bertahan dalam persaingan.

Tanpa adanya kebijakan dan pengendalian manajemen yang baik, suatu perusahaan akan sulit untuk menjalankan usahanya, dan hanya perusahaan yang dapat melaksanakan strategi yang telah ditetapkan yang akan dapat bertahan dalam persaingan, serta mempunyai kesempatan untuk berkembang lebih baik.

Perkembangan teknologi informasi saat ini banyak memberikaan kemudahan pada berbagai aspek kegiatan perusahaan. Teknologi informasi merupakan bagian dari sistem informasi dan teknologi informasi merujuk pada teknologi yang digunakan dalam menyampaikan maupun mengolah informasi. Teknologi informasi adalah suatu teknologi yang berhubungan dengan pengolahan data menjadi informasi dan proses penyaluran data atau informasi dalam batasan ruang dan waktu. Teknologi ini dapat dimanfaatkan untuk pengembangan sistem pencatatan dan pengelolahan data.

Teknologi mempermudah sarana informasi banyak digunakan pada perusahaan, terutama perusahaan yang bergerak dibidang jasa, salah satunya adalah Badan Penyelenggara Jaminan Sosial (BPJS) Ketenagakerjaan. BPJS Ketenagakerjaan merupakan salah satu perusahaan yang bergerak di bidang jasa layanan publik yang selalu mengembangkan kualitas layanan serta informasinya untuk meningkatkan kepuasan pelanggan.

Penggunaan teknologi tidak luput dari perhatian BPJS Ketenagakerjaan, 
aplikasi berbasis website pun dibuat oleh BPJS Ketenagakerjaan untuk mempermudah dan mempercepat layanan kepada pelanggan, Ada dua macam sistem pelaporan peserta yang diterapkan BPJS Ketenagakerjaan yaitu dengan pelaporan berbasis konvensional dan pelaporan Online dengan menggunakan aplikasi berbasis website yaitu Sistem Informasi Pelaporan Peserta Online. Berdasarkan uraian tersebut, maka pokok permasalahan yang akan dianalisis dan dibahas oleh peneliti adalah bagaimana efektivitas dan efisiensi pelaporan tenaga kerja dengan menggunakan sistem manual dan sistem Online (Studi kasus BPJS Ketenagakerjaan Cabang Gresik)

\section{TINJAUAN PUSTAKA \\ Penelitian Terdahulu}

Penelitian yang dilakukan oleh Sutatik tahun 2014, dengan judul Analisis Perbandingan Pelayanan Publik Dengan Sistem Manual Dan Online (Studi Pembayaran Rekening Listrik Di Perusahaan Listik Negara Kota Samarinda.Penelitian ini menggunakan metode kualitatif, dalam penelitian ini dijelaskan bahwa Perbandingan pelayanan publik dalam pembayaran rekening listrik dengan sistem manual dan Online bisa dilihat dari hal mekanisme, biaya dan waktu.

\section{Kajian Pustaka}

Informasi merupakan hasil pengolahan data sehingga menjadi bentuk yang penting bagi penerimanya dan mempunyai kegunaan sebagai dasar dalam pengambilan keputusan yang dapat dirasakan akibatnya secara langsung saat itu juga atau secara tidak langsung pada saat mendatang. Untuk memperoleh informasi, diperlukan adanya data yang akan diolah dan unit pengolah (Sutanta, 2003:10). Sebuah sistem informasi (SI) bisa terdiri atas kombinasi terorganisasi apapun dari manusia, perangkat keras, perangkat lunak, jaringan komunikasi, sumber data, dan kebijakan serta prosedur yang terorganisir menyimpan, mengambil, mengubah, dan memisahkan informasi dalam sebuah organisasi (O'Brien dan Marakas, 2014;4).

\section{Pelaporan Tenaga Kerja}

Undang-undang nomor 7 Tahun 1981 tentang wajib lapor ketenagakerjaan di perusahaan mewajibkan setiap pengusaha atau pengurus perusahaan untuk melaporkan secara tertulis kepada mentri atau pejabat yang berwenang selambat-lambatnya dalam jangka waktu 30 (tiga puluh) hari setelah mendirikan, menjalankan kembali atau memindahkan perusahaan. Berdasarkan pasal (2) peraturan mentri tenaga kerja dan transmigrasi no.PER.14/MEN/IV/2006 tentang tata cara pelaporan tenaga kerja diperusahaan, pengusaha wajib membuat laporan mengenai ketenagakerjaan sesuai dengan keadaan yang sebenarnya baik pada kantor pusat, cabang maupun pada bagian perusahaan yang berdiri sendiri.

\section{Efektivitas}

Kata efektif berasal dari Bahasa inggris effective artinya berhasil. Sesuatu yang dilakukan berhasil dengan baik. Menurut Robbins (dalam Indrawijaya, 2010;175) mendefinisikan efektivitas sebagai tingkat pencapaian organisasi jangka pendek (tujuan) dan jangka panjang (cara). Pencerminan itu mencerminkan konstituensi strategis, minat mengevaluasi, dan tingkat kehidupan organisasi.

Menurut pendapat David, dkk (dalam Sudarwan, 2004;119) menyebutkan ukuran efektivitas sebagai berikut: 
1. Jumlah hasil yang dikeluarkan, artinya hasil tersebut dapat berupa kuantitas atau bentuk fisik dari organisasi, program, kegiatan. Hasil tersebut dapat dilihat dari perbandingan ratio antara masukan (input) dan luaran (output)

2. Tingkat kepuasan yang diperoleh, artinya ukuran dalam efektivitas ini dapat kuantitatif (berdasarkan pada jumlah atau banyaknya) dan dapat kualitatif (berdasarkan pada mutu)

3. Produk kreatif, artinya penciptaan hubungan kondisi yang kondusif dengan dunia kerja, yang nantinya dapat menambahkan kreativitas dan kemampuan.

4. Intensitas yang akan dicapai, artinya memiliki ketaatan yang tinggi dalam suatu tingkatan intens sesuatu, dimana adanya rasa saling memiliki dengan kadar yang tinggi.

\section{Efisiensi}

Efisiensi merupakan rasio antara output dan input. Perbandingan antara masukan dan keluaran. Maksud dari masukan serta bagaimana angka perbandingan tersebut diperoleh, akan tergantung dari tujuan penggunaan tolok ukur. Efisiensi dapat diartikan sebagai perbandingan antara keluaran (output) dengan masukan (input), atau jumlah keluaran yang dihasilkan dari satu input yang digunakan.

Input adalah semua sumber yaitu sarana dan prasarana yang digunakan dalam kegiatan operasional, misal tenaga kerja, biaya bahan pokok, peralatan atau mesin, dll. Sedangkan output adalah hasil dari pada pekerjaan dalam istilah ekonomi yaitu hasil produksi yang berwujud barang atau jasa. Sementara itu, efisiensi di dalam konsep produksi cenderung menilai secara teknis dan oprasional, sehingga efisiensi ini di dalam konsep produksi umumnya melihat dari sudut pandang teknis dan biaya.

\section{METODOLOGI PENELITIAN}

Penelitian ini menggunakan metode deskriptif komparatif dengan pendekatan kualitatif. Metode ini dapat diartikan sebagai metode penelitian yang berlandaskan pada filsafat postpositivismelenterpretif, digunakan untuk meneliti pada kondisi obyek yang alamiah, (sebagai lawannya adalah eksperimen) dimana peneliti sebagai instrumen kunci.

Komparatif adalah penelitian yang membandingkan keberadaan satu variabel atau lebih pada dua atau lebih sampel yang berbeda, atau pada waktu yang berbeda. Penggunaan metode deskriptif-komparatif dalam penelitian ini adalah membandingkan sistem pelaporan menggunakan sistem manual dan Online di kantor BPJS Ketenagakerjaan. Lokasi penelitian merupakan suatu tempat atau wilayah dimana penelitian akan dilakukan.

Dalam penelitian ini, peneliti melakukan penelitian di kantor BPJS Ketenagakerjaan cabang Gresik di jalan Wahidin Sudirohusodo No 121A Ngipik, Kecamatan Gresik, Kabupaten Gresik, Jawa Timur. Teknik pengumpulan data merupakan langkah yang paling utama dalam penelitian, karena tujuan utama dari penelitian adalah mendapatkan data. Tanpa mengetahui teknik pengumpulan data, maka peneliti tidak akan mendapatkan data yang memenuhi standart data yang ditetapkan (Sugiyono, 2015;375).

Pengumpulan data yang akan dilakukan oleh peneliti adalah Wawancara/interview, Observasi, dan Dokumentasi. peneliti menentukan Divisi Pemasaran sebagai unit 
analisisnya, dikarenakan divisi pemasaran merupakan fokus penelitian yang akan dilakukan oleh peneliti. Penentuan Key Informent didasarkan pada informent yang mengetahui secara jelas dan tepat informasi mengenai masalah dalam penelitian ini.

Menurut Bungin (2007:53), penentuan Informan yang terpenting dalam penelitian kualitatif adalah bagaimana menentukan key informent atau situasi sosial tertentu yang menjadikan informasi sesuai dengan fokus penelitian. Informen dalam penelitian ini adalah:

1. Kepala Bidang Pemasaran

2. Relationship Officer (RO)

3. Marketing Officer (MO)

4. Peserta pengguna sistem manual

5. Peserta pengguna sistem Online

Teknik analisis yang digunakan oleh peneliti adalah Teknik Analisis Perbandingan Tetap. Dinamakan metode perbandingan tetap atau Constant Comparative Method karena dalam analisis data, secara tetap membandingkan satu datum dengan datum yang lain, dan kemudian secara tetap membandingkan kategori dengan kategori yang lainnya.

\section{HASIL PENELITIAN}

\section{Gambaran Umum Obyek Penelitian}

Penyelenggaraan program jaminan sosial merupakan salah satu tanggung jawab dan kewajiban negara untuk memberikan perlindungan sosial ekonomi kepada masyarakat. Sesuai dengan kondisi kemampuan keuangan Negara Indonesia seperti halnya Negara berkembang lainnya, mengembangkan program jaminan sosial berdasarkan funded social security, yaitu jamina sosial yang didanai oleh peserta dan masih terbatas pada masyarakat pekerja di sektor formal.
Sejarah terbentuknya PT Jamsostek (Persero) mengalami proses yang panjang, dimulai dari UU No.33/1947 UU No.2/1951 tentang kecelakaan kerja. Peraturan Menteri Perburuhan (PMP) No.48/1952 PMP No.8/1956 tentang pengaturan bantuan untuk usaha penyelenggara kesehatan buruh, PMP No.15/1957 tentang pembentukan yayasan sosial buruh, PMP No.5/1964 tentang pembentukan yayasan dana jaminan sosial (YDJS) diberlakukan UU No.14/1969 tentang pokok-pokok tenaga kerja. Secara kronologis proses lahirnya asuransi sosial tenaga kerja semakin transparan.

Setelah mengalami kemajuan dan perkembangan, baik menyangkut landasan hukum, bentuk perlindungan, maupun cara penyelenggaraan, pada tahun 1977 diperoleh suatu tonggak sejarah penting dengan dikeluarkannya Peraturan Pemerintah (PP) No.33 tahun 1977 tentang pelaksanaan program asuransi sosial tenaga kerja (ASTEK), yang mewajibkan setiap pemberi kerja/pengusaha swasta dan BUMN untuk mengikuti program ASTEK. Terbit pula PP No.34/1977 tentang pembentukan wadah penyelenggara ASTEK yaitu Perum Astek.

Tonggak penting berikutnya adalah lahirnya UU No.3 tahun 1992 tentang Jaminan Sosial Tenaga Kerja (JAMSOSTEK), dan melalui PP No.36/1995 ditetapkannya PT Jamsostek sebagai badan penyelenggara Jaminan Sosial Tenaga Kerja. Program Jamsostek memberikan perlindungan dasar untuk memenuhi kebutuhan minimal bagi tenaga kerja dan keluarganya, dengan memberikan kepastian berlangsungnya arus penerimaan penghasilan keluarga sebagai pengganti sebagian atau seluruhnya penghasilan yang hilang akibat resiko sosial. 
Selanjutnya pada akhir tahun 2004, Pemerintah juga menerbitkan Nomor 40 tahun 2004 tentang Sistem Jaminan Sosial Nasional. Undangundang itu berhubungan dengan Amandemen UUD 1945 tentang perubahan pasal 34 ayat 2, yang kini berbunyi: "Negara mengembangkan sistem jaminan sosial bagi seluruh rakyat dan memberdayakan masyarakat yang lemah dan tidak mampu sesuai dengan martabat kemanusiaan". Manfaat perlindungan tersebut dapat memberikan rasa aman kepada pekerja sehingga dapat lebih berkonsentrasi dalam meningkatkan motivasi maupun produktivitas kerja.

Kiprah Perusahaan PT Jamsostek (Persero) yang mengedepankan kepentingan dan hak normative tenaga kerja di Indonesia dengan memberikan perlindungaan 4 (empat) program, yang mencakup Program Jaminan Kecelakaan Kerja (JKK), Jaminan Kematian (JK), Jaminan Hari Tua (JHT), dan Jaminan Pemeliharaan Kesehatan (JPK) bagi seluruh tenaga kerja dan keluarganya hingga berlakunya UU No24 Tahun 2011.

Badan Penyelenggara Jaminan Sosial. Sesuai dengan undang-undang tanggal 1 januari 2014 PT Jamsostek akan berubah menjadi badan hukum publik. PT Jamsostek (Persero) yang bertransformasi menjadi BPJS (Badan penyelenggara Jaminan Sosial) ketenagakerjaan tetap dipercaya untuk menyelenggarakan program jaminan sosial tenaga kerja meliputi JKK, JKM, JHT dengan penambahan Jaminan Pensiun (JP) mulai 1 Juli 2015.

\section{HASIL PENELITIAN}

\section{Proses Pelaporan Secara Manual} Proses pelaporan dengan menggunakan sistem manual dilakukan dengan cara mengisi formulir sesuai dengan kondisi yang akan dilaporkan yaitu dengan mengisi formulir seperti formulir tenaga kerja masuk atau baru, formulir tenaga kerja keluar, dan upah tenaga kerja, formulir tersebut bisa diambil atau didapat melalui kantor BPJS Ketenagakerjaan. Formulir yang sudah di isi dengan data-data tenaga kerja yang akan dilaporkan selanjutnya dibawa dan diserahkan kepada pembina perusahaan dalam hal ini adalah Relationship Officer (RO)

\section{Proses Pelaporan Secara Online}

Aplikasi Sistem Informasi Pelaporan Peserta Online (SIPP Online) adalah salah satu sistem aplikasi terpadu dari BPJS Ketenagakerjaan yang digunakan untuk pengelolaan laporan data tenaga kerja termasuk diantaranya adalah pelaporan mutasi, update jumlah data tenaga kerja, dan update data upah tenaga kerja. Aplikasi Sistem Informasi Pelaporan Perusahaan Online, pengguna/perusahaan dapat mengupdate data perusahaan, menambah tenaga kerja, mengedit data tenaga kerja, Menonaktifkan tenaga kerja, meng-update data upah tenaga kerja, melaporkan kecelakaan kerja tenaga kerja, serta melakukan monitoring iuran. Dalam hal ini orang yang dimaksud adalah admin atau personalia perusahaan. Proses pelaporan secara Online dilakukan dengan menggunakan aplikasi berbasis web yang bisa diakses melalui http//www.sipp.bpjsketenagakerja an.go.id dengan cara mendaftarkan Nomor Pendaftaran Perusahaan (NPP) yang nantinya mendapatkan Username dan Password untuk mengakses aplikasi tersebut. 
3. Pelayanan Pelaporan Secara Manual

Pelayanan adalah proses pemenuhan kebutuhan melalui aktivitas orang lain secara langsung. Pengertian pelayanan dalam kamus bahasa Indonesia adalah menolong menyediakan segala apa saja yang diperlukan orang lain seperti tamu atau pembeli. Dari hasil wawancara yang dilakukan oleh peneliti kepada beberapa peserta, Pelaporan dilakukan secara manual butuh waktu yang lebih lama dalam setiap prosesnya. Akan tetapi pelayanan secara manual juga memiliki sisi positif, diantaranya yaitu sebagai alternatif jika terdapat kendala atau trouble pada proses pelaporan secara Online.

4. Pelayanan Pelaporan Secara Online

Pelayanan pelaporan secara Online bisa secara langsung dengan menggunakan aplikasi atau web yang sudah disediakan oleh pihak BPJS Ketenagakerjaan yaitu aplikasi Sistem Informasi Pelaporan Peserta Online atau SIPP Online. Pelayanannya sudah tidak lagi menggunakan atau menyerahkan berkas-berkas data atau formulir-formulir tenaga kejra. Manfaat dari pelaporan secara Online adalah memberikan kemudahan bagi perusahaan agar tidak perlu lagi datang dan menyerahkan berkas ke kantor BPJS Ketenagakerjaan.

\section{PEMBAHASAN}

Analisis Efektivitas Pelaporan Secara Manual

Efektivitas merupakan pengukuran dalam arti tercapainya sasaran atau tujuan yang telah ditentukan oleh perusahaan sebelumnya, sebuah pengukuran dimana suatu target telah tercapai sesuai dengan apa yang telah direncanakan yang menekankan pentingnya efektivitas dalam pencapaian tujuan-tujuan organisasi dimana efektivitas merupakan kunci dari kesuksesan suatu organisasi. Pelaporan yang dilakukan secara manual membutuhkan waktu yang lebih lama dalam setiap prosesnya, akan tetapi pelaporan secara manual juga memiliki sisi positif diantaranya adalah Pelayanan pelaporan secara manual bisa mempertemukan kedua belah pihak antara perusahaan yang akan melaporkan tenaga kerjanya dengan pihak Relationship Officer atau Marketing Officer BPJS Ketenagakerjaan. Hal ini akan menimbulkan hubungan yang lebih baik antara keduanya, karena akan mengurangi resiko terjadinya pelanggaran seperti Perusahaan Daftar Sebagian (PDS), pelaporan upah yang tidak sesuai, dan juga pembayaran iuran kepesertaan tidak tepat waktu.

Berikut adalah pengukuran efektivitas berdasarkan teori indikator efektivitas yang digunakan oleh peneliti.

1. Jumlah Yang Dikeluarkan

Pada proses pelaporan yang dilakukan secara manual, perusahaan diharuskan mengisi formulir sesuai dengan apa yang dilaporkan seperti formulir tenaga kerja masuk, formulir tenaga kerja keluar, dan upah tenaga kerja, yang selanjutnya formulir tersebut harus diserahkan kepada pembina perusahaan yaitu RO atau MO BPJS Ketenagakerjaan. Setelah data diterima oleh BPJS Ketenagakerjaan, maka data tersebut akan diproses atau di input ke dalam sistem mereka dan otomatis tenaga kerja yang dilaporkan tersebut sudah berhak mendapatkan perlindungan sesuai 
dengan program yang di ikuti seperti jaminan hari tua, jaminan kecelakaan kerja dan jaminan kematian. Dalam satu hari pihak RO maupun MO BPJS Ketenagakerjaan tidak bisa secara langsung memasukkan data-data yang diterima ke dalam sistem mereka, dikarenakan banyaknya data yang akan di input dan juga pihak RO maupun $\mathrm{MO}$ mempunyai tugas untuk mencari kepesertaan baru atau dinas ke luar kantor. Akan tetapi meskipun data-data tersebut belum dimasukkan kedalam sistem BPJS, tenaga kerja tersebut juga sudah mendapatkan perlindungan dengan catatan pembayaran iuran kepesertaan tidak jatuh tempo atau sesuai dengan tenggang waktu yang telah ditentukan dan telah mendapat stampel dokumen diterima.

2. Tingkat Kepuasan Yang Diperoleh Dalam proses pelaporan secara manual perusahaan harus menyerahkan berkas kepada BPJS Ketenagakerjaan yaitu dengan menemui dan menyerahkan berkas kepada pembinanya masingmasing. Dalam hal ini perusahaan harus mengantri untuk bertemu dengan pembina perusahaan (RO dan MO) karena setiap RO maupun MO mempunyai banyak perusahaan binaan yang mencapai lebih dari dua ribu perusahaan baik perusahaan kecil, perusahaan menengah, dan perusahaan besar. Akan tetapi walaupun harus mengantri, sisi baiknya adalah perusahaan dan pihak RO maupun MO bisa bertemu langsung dan menjaga hubungan yang baik antara keduanya agar terhindar dari pelanggaranpelanggaran seperti Perusahaan Daftar Sebagian (PDS), tunggakan iuran kepesertaan, dan lain-lain.

3. Produk kreatif
Proses pelaporan secara manual dilakukan dengan mengisi formulir dan diserahkan kepada BPJS Ketenagakerjaan. Masalah yang ada didalam proses penyerahan berkas tersebut terkadang perusahaan tersebut tidak bisa bertemu dengan pembinanya, maka harus diterima oleh pembina yang lainnya, yang bisa berakibat kehilangan data-data tersebut karena human error atau kesalahan dalam penyimpanan berkas tersebut.

4. Intensitas Yang Akan Dicapai Tujuan dari pelaporan tenaga kerja adalah agar tenaga kerja yang dilaporkan segera mendapatkan perlindungan dan terhindar dari resiko dari kecelakaan kerja dan kematian. Jika perusahaan belum menyerahkan data-data tenaga kerjanya untuk dilaporkan atau pihak RO maupun MO belum memproses data-data yang diterima dan tenaga kerja tersebut sudah datang untuk melakukan klaim, maka klaim tersebut akan tidak bisa terproses.

\section{Analisis Efektivitas Pelaporan Secara Online}

Pelaporan secara Online bisa dilakukan secara langsung menggunakan komputer dan di akses melalui aplikasi yang sudah disediakan oleh pihak BPJS Ketenagakerjaan, yaitu Sistem Informasi Pelaporan Peserta Online atau SIPP Online. Dalam penerapannya proses pelaporan secara Online memerlukan lima sumber daya diantaranya adalah sumber daya manusia, sumber daya perangkat keras, sumber daya perangkat lunak, sumber daya data dan sumber daya jaringan. Kelima sumber daya ini adalah modal 
yang harus dimiliki oleh sebuah perusahaan untuk bisa menggunakan pelaporan tenaga kerja secara Online. Pelaporan secara Online banyak memberikan kemudahan bagi pihak perusahaan maupun pihak dari BPJS Ketenagakerjaan. Adapun juga pelaporan secara Online mempunyai sisi kekurangan dalam penerapannya. Berikut ini adalah pengukuran efektivitas berdasarkan teori indikator yang digunakan oleh peneliti

1. Jumlah yang dikeluarkan

Pada proses pelaporan yang dilakukan secara Online, perusahaan tidak lagi memakai formulir atau merekap data tenaga kerja yang dilaporkan dan tidak harus datang ke kantor BPJS Ketenagakerjaan. Perusahaan dapat melaporkan kapan pun tenaga kerjanya secara Online 24 jam dengan menggunakan aplikasi yang sudah disediakan melalui SIPP Online.

2. Tingkat kepuasan yang diperoleh Sejauh ini proses pelaporan yang dilakukan secara Online sudah banyak memberikan banyak kemudahan bagi perusahaan maupun pembina ( $\mathrm{RO}$ dan $\mathrm{MO}$ ) karena semakin cepat dalam proses pelaporannya, akan tetapi dalam proses penerapan pelaporan secara Online ini tidak selalu berjalan dengan baik, karena sistem Online juga bisa mengalami trouble dalam penerapannya. Jika system mengalami trouble maka pelaporan akan dialihkan menggunakan pelaporan secara manual.

3. Produk Kreatif

Dengan menggunakan pelaporan secara Online maka perusahaan sudah memanfaatkan layanan yang diberikan BPJS Ketenagakerjaan berupa pemanfaatan teknologi yang tersedia yaitu aplikasi Sistem
Informasi Pelaporan Peserta atau SIPP Online. Akan tetapi jika menggunakan pelaporan secara Online maka hubungan dan komunikasi hanya bisa dilakukan secara jarak jauh atau menggunakan telfon dan grup yang telah dibuat.

4. Intensitas yang akan dicapai

Dengan sistem Online perusahaan sangat dimudahkan, karena dengan penerapan secara Online dapat mengatasi keterlambatan data yang diberikan oleh perusahaan, dengan menggunakan aplikasi Online ini perusahaan semakin cepat melakukan perubahan data, perusahaan juga semakin cepat memudahkan tenaga kerjanya untuk bisa melakukan klaim seperti Jaminan Kecelakaan Kerja, Jaminan Kematian dan Jaminan Hari Tua.

\section{Analisis Efisiensi Pelaporan Manual}

Efisiensi pelaporan secara manual dapat diukur dengan menggunakan indikator efisiensi sebagai berikut:

1. Penggunaan pikiran

Dalam pelaporan secara manual perusahaan harus mengumpulkan dan merekap data-data tenaga kerja yang akan dilaporkan dengan formulir yang berbeda-beda sesuai dengan perubahan yang terjadi seperti data tenaga kerja masuk, data tenaga kerja keluar dan perubahan upah tenaga kerja yang selanjutnya data-data tersebut diserahkan kepada pembina perusahaan yaitu RO atau MO. Setelah data diterima oleh pembina perusahaan maka data tersebut selanjutnya akan dimasukkan ke dalam sistem mereka. 
2. Penggunaan tenaga

Efisiensi yang ditinjau dari peserta atau perusahaan yaitu semakin banyak pelaporan secara manual akan semakin bertambah pula antriannya, sedangkan dari pihak pembina perusahaan yaitu RO dan MO tidak bisa keluar untuk mencari kepesertaan baru karena harus mengentri data-data yang telah masuk dan fungsi pemasarannya menjadi berkurang karena harus mengentri berkas.

3. Penggunaan waktu Perusahaan yang akan melaporkan tenaga kerjanya harus datang ke kantor BPJS Ketenagakerjaan untuk menyerahkan data-data yang akan dilaporkan. Dan pihak pembina perusahaan yaitu RO dan MO harus membagi waktu antara dinas keluar untuk mencari kepesertaan baru dan tetap di kantor untuk menerima berkas dari perusahaan.

4. Penggunaan ruang

Data-data yang diterima oleh RO maupun MO yang berupa formulirformulir data tenaga kerja memerlukan ruang penyimpanan khusus agar nantinya jika data tersebut dibutuhkan kembali maka akan mudah untuk ditemukan.

5. Penggunaan benda

Data-data yang diserahkan oleh perusahaan maupun yang diterima oleh pembina perusahaan yaitu berupa berkas fisik atau hardcopy

\section{Analisis Efisiensi Pelaporan Online}

Efisiensi pelaporan secara Online dapat diukur dengan menggunakan indikator efisiensi sebagai berikut:

1. Penggunaan Pikiran

Perusahaan tidak perlu lagi merekap data, dapat langsung menggunakan aplikasi SIPP Online yang sudah disediakan oleh pihak BPJS Ketenagakerjaan. Pembina perusahaan juga tidak perlu lagi untuk mengentri data ke sistem

2. Penggunaan tenaga

Proses pelaporan secara Online bisa dilakukan secara langsung tanpa merekap data terlebih dahulu dan menyerahkan berkas tersebut kepada pembina perusahaan.

3. Penggunaan waktu

Proses pelaporan secara Online bisa dilakukan secara langsung dan kapanpun selama 24 jam penuh dengan menggunakan aplikasi SIPP Online yang sudah disediakan oleh pihak BPJS Ketenagakerjaan.

4. Penggunaan ruang

Karena proses pelaporannya sudah tidak menggunakan manual maka berkas atau data tenaga kerja sudah tersimpan didalam akun database SIPP Online perusahaan dan juga di sistem BPJS Ketenagakerjaan. Nantinya akan mudah dicari jika data tersebut dibutuhkan kembali

5. Penggunaan benda

Sudah tidak lagi menggunakan berkas fisik atau hardcopy berupa kertas, hanya menggunakan berkas berbentuk softcopy

\section{KESIMPULAN \\ REKOMENDASI}

DAN

\section{Kesimpulan}

Berdasarkan hasil penelitian tentang analisis efektivitas dan efisiensi pelaporan tenaga kerja dengan menggunakan sistem manual dan sistem Online (Studi kasus BPJS Ketenagakerjaan) maka dapat ditarik beberapa kesimpulan sebagai berikut

1) Pelaporan tenaga kerja secara Online memberikan banyak kemudahan kepada setiap perusahaan atau penggunanya dan juga kepada pihak BPJS Ketenagakerjaan khusunya Relationship Officer dan Marketing Officer yang bertugas sebagai 
pembina perusahaan tanpa harus melalui proses yang panjang yang akan mengakibatkan keterlambatan atau kehilangan data-data tenaga kerja yang dilaporkan.

2) Pelaporan secara manual mempunyai sisi positif yaitu perusahaan dan pihak RO maupun MO bisa bertemu langsung dan menjaga hubungan yang baik antara keduanya agar terhindar dari pelanggaran-pelanggaran seperti Perusahaan Daftar Sebagian (PDS), tunggakan iuran kepesertaan, dan lain-lain

3) Penggunaan pelaporan secara manual dapat dijadikan sebagai alternatif jika terdapat kendalakendala yang dihadapi pada saat proses pelaporan secara Online sedang berjalan, agar perusahaan bisa melaporkan tenaga kerja dan melakukan pembayaran iuran kepesertaan tepat waktu dan terhindar dari denda.

\section{Rekomendasi}

Berdasarkan hasil penelitian yang dilakukan, maka peneliti memberikan rekomendasi sebagai berikut:

1) Bagi pihak BPJS Ketenagakerjaan untuk dapat mengurangi resiko terjadinya keterlambatan atau tidak terprosesnya data, pihak BPJS Ketenagakerjaan tentunya harus meningkatkan kualitas sistem serta pelayanannya terhadap perusahaan atau pesertanya dengan cara mengupgrade data-data dari Dispenduk setiap satu bulan sekali.

2) Pada penelitian selanjutnya sebaiknya menambahkan variabel kinerja bagi karyawan divisi pemasaran guna mengetahui bagaimana kualitas, kuantitas, ketepatan waktu, efektivitas dan kemandirian karyawan

\section{DAFTAR PUSTAKA}

Aini, B. S. 2017. "Faktor Penentu Kualitas Layanan dan Minat Untuk Melanjutkan Penggunaan Sistem Pelaaporan Online". Jurnal Economia, Vol 13. No 2 2017, 128-140.

Anwar. 2016. Pedoman Penulisan Proposal \& Skripsi, Edisi Revisi, UMG. Gresik.

Bungin. 2007. Penelitian Kualitatif: Komunikasi, Ekonomi, Kebijakan Publik dan Ilmu Sosial Lainnya. Jakarta: Putra Grafika.

Hasibuan. 2010. Manajemen Sumber Daya Manusia. Jakarta: Bumi Aksara.

Indrawan, Y. 2014. Metode Penelitian Kuantitatif, Kualitatif, dan Campuran untuk Manajemen, Pembangunan, dan Pendidikan. Bandung: Reflika Aditama.

Indrawijaya. 2010. Teori, Perilaku, dan Budaya Organisasi. Bandung: Reflika.

Liang, Gie. T. 2009. Administrasi Perkantoran. Yogyakarta: Modern Liberty.

Moleong. 2014. "Metodologi Penelitian Kualitatif". Remaja Rosdakarya, Bandung.

Mulyadi. 2007. Sistem Perencanaan dan Pengendalian Manajemen. Jakarta: Salemba Empat.

O'Brien, M. 2014. "Sistem Informasi Manajemen". Salemba Empat, Jakarta. 
Oktriyana, Y. 2017. "Analisis Sistem Pembayaran Premi Asuransi Secara Online Terhadap Kinerja Agensi Pada AJB Bumiputra Cabang Denpasar". Jurnal akutansi Vol 7 No 1 Tahun 2017, 1-12.

Robbins, S. 2011. Organizational Behavior. Boston: Pearson.

Steers, M. R. 1985. Efektivitas Organisasi. Jakarta: Erlangga

Sudarwan. 2004. Motivasi Kepemimpinan \& Efektivitas Kelompok . Jakarta: Rineka Cipta.

Sugiyono. 2015. "Metode Penelitian Manajemen". Alfabeta, Bandung.

Sukirno, Sadono. 2008. Mikro Ekonomi: Teori Pengantar Edisi Ketiga. Jakarta: PT Raja Grafindo Persada

Sukmalaras, i. f. 2015. "Analisis Perbandingan Pelaporan Pelelangan Manual Dengan EProcurement Terhadap Pelaksanaan Proyek Konstruksi di Kabupaten Garut". jurnal konstruksi Vol. 13 No. 1 2015, 19.

Sutatik. 2014. "Analisis Perbandingan Pelayanan Publik Dengan Sistem Manual dan Online (Studi Pembayaran Rekening Listrik di Kota Samarinda)". eJournal Ilmu Pemerintahan, 3374-3385.

Tangklisan, N. H. 2005. Manajemen Publik. Jakarta: Gramedia Widiasarana Indonesia
Undang-undang Nomor 7 Tahun 1981 Tentang Wajib Lapor Ketenagakerjaan. 